\title{
SPINAL CORD INJURIES IN CHILDREN IN BRITISH COLUMBIA
}

\author{
By Leslie G. Andrews, M.B., B.S., D.C.H., D.Phys.Med., F.R.C.P.(C.) \\ and SuSAN K. JUnG, M.D. \\ G. F. Strong Rehabilitation Centre, Vancouver, B.C., Canada
}

\begin{abstract}
Fifteen children who sustained traumatic spinal cord injury in British Columbia over a I3-year period have been reviewed. The aetiology, incidence of spinal fracture, length of hospitalisation and subsequent spinal surgery, and their self-care, transfer and ambulatory abilities, bowel and bladder management, schooling, employment and place of abode have been determined.
\end{abstract}

Key words: Spinal cord injury; Spinal fracture; Self-care; Transfers; Ambulation; Bowel and bladder control; Scoliosis; Spinal surgery; Education; Employment.

\section{Introduction}

SPINAL cord trauma in children below the age of 13 is uncommon compared with the incidence in teenagers and adults. Whilst pedestrian and passenger accidents are common, children are not exposed to driving a motor vehicle, or industrial accidents.

Burke (I97I, I974) and Cheshire (I977) reported a low incidence of spinal fractures in paediatric spinal cord trauma, due to hyperflexion or hyperextension injury. Little is known of the pathological changes to the vertebral column and spinal cord due to the scarcity of material and published autopsies (Burke, I97I, I974; Glasauer \& Cares, I972; Cheshire, I977). Complications following spinal cord injuries in children are similar to those seen in adults, but their severity and incidence differ. Post-traumatic spinal deformity, kyphoscoliosis, is relatively common in young children and rare in adults (Burke, 1976). Guttmann (1969) first drew attention to the danger of laminectomy increasing the risk of spinal deformity.

The life expectancy of children with traumatic quadriplegia or paraplegia is still uncertain since most children have been treated in a variety of centres or hospitals, and the few reported surveys have only been able to assemble low numbers of cases. Literature is sparse on the level of independence these children achieve.

\section{Method}

A survey was carried out on the children in British Columbia (B.C.) injured below the age of $\mathrm{I}_{3}$, to determine the causes, incidence of spinal fracture, length of stay in hospital, and subsequent spinal surgery. Their current status was also reviewed including self-care, transfer and ambulatory abilities, bowel and bladder management, schooling, employment and place of abode. Spinal scoliosis and urinary tract deterioration were especially looked for.

This review encompassed children who had sustained traumatic spinal cord injury from 3I December I964 to 3I December 1977. The cases were obtained from the Health Surveillance Registry of B.C., and the Medical Record Depart- 
ment of the G. F. Strong Rehabilitation Centre, and Sunny Hill Hospital for Children.

Until an Acute Spinal Cord Injury Unit was opened in Vancouver, B.C., in 1975, initial treatment was carried out in a variety of hospitals throughout the province. Cases were then usually referred to the G. F. Strong Rehabilitation Centre.

Fifteen patients were contacted. Eleven had been under the care of one of us (L. G. A.) during most of their lives. This probably represents all of the cases in B.C. during this period other than one or two who may not have been reported to the Registry.

In some cases, I3 years had elapsed since the onset. Children with paralysis due to birth injuries were excluded. Penetrating injuries due to gunshot wounds were included.

Each patient's chart was reviewed and a questionnaire was completed by personal or telephone contact with the patient and/or one of their parents.

The questionnaire was specific and based on the following definitions:

I. Continence of urine-not more than two accidents per month.

2. Continence of faeces-not more than two accidents per month.

3. Wheelchair case-complete dependence on a wheelchair.

4. Ambulatory-this included using a wheelchair but not more than twice per month.

5. Exercise standers or walkers-those who were wheelchair/partially 'ambulatory', not falling into the above two definitions.

6. Self-care complete-this included those unable to do one item of selfcare. If the patient was unable to perform two or more items, his self-care was classified as incomplete.

\section{Results}

Age and sex. There were I I children below ro years of age at the time of injury, and four over ro years (Table I). Of these, nine were boys and six were girls.

Aetiology. The commonest cause was a motor vehicle accident (Table II). The patients included both passengers and pedestrians. Two of the latter were riding

TABLE I

Age distribution

\begin{tabular}{rr}
\hline I- 4 years & 5 \\
$5-9$ years & 6 \\
IO-I3 years & 4 \\
\hline
\end{tabular}

TABLE II

Cause of spinal cord injury

Motor vehicle passenger

'Pedestrian' knocked over by vehicle

Struck by falling or moving heavy object

Gunshot wound 
their bicycles, and five were struck by a car or bus whilst running or walking. Two had gunshot wounds accidentally inflicted by older brothers, aged 12 and I5. Three resulted from heavy objects falling on their backs (bale of telephone wire; jacked up trailer; and collapse of an overhanging clay bank).

Neurological level. Eleven cases were spastic and four were flaccid. In the flaccid patients the lesion was at Tio or below. Thirteen patients had complete and two had incomplete lesions (Table III).

Radiological findings. There was a crush fracture of a vertebral body in four patients. These included all three cord injuries due to a heavy object falling on the back. Three patients had a fracture dislocation. There were no radiological findings in seven patients. No patients had had tomography.

Associated injuries. These were predominantly bony fractures mainly in the limbs and ribs, visceral injuries to the kidneys and lungs, and head injuries. All of five patients with a head injury (Table IV) had been unconscious from I hour to 7 days. Fractures independent of the spinal column were sometimes multiple.

Survival. All I5 patients were alive. Four had survived more than Io years from the date of the accident (Table V).

Operation at the time of injury. There was no operative intervention in 12 patients (Table VI). In the three who underwent surgery, two had a decompression

TABLE III

Neurological level

\begin{tabular}{lccll}
\hline T4 4 and above & C8 & I & Spastic & Complete \\
& $\mathrm{TI}$ & 2 & Spastic & Complete \\
& $\mathrm{T}_{3}$ & 3 & Spastic & Complete \\
& $\mathrm{T}_{4}$ & 3 & Spastic & Complete \\
Below T4 & T6 & I & Spastic & Complete \\
& TIO & I & Spastic & Incomplete \\
& TIO & I & Flaccid & Complete \\
& TII & I & Flaccid & Complete \\
& TI2 & I & Flaccid & Complete \\
& Cauda equina & I & Flaccid & Incomplete \\
\hline
\end{tabular}

TABLE IV

Associated injuries

\begin{tabular}{|c|c|c|c|}
\hline Head injuries & 5 & & \\
\hline \multirow{3}{*}{ Other fractures } & \multirow[b]{2}{*}{ I5 } & $\left\{\begin{array}{l}\text { Ribs } \\
\text { Skull }\end{array}\right.$ & $\begin{array}{l}4 \\
2\end{array}$ \\
\hline & & Limbs & 8 \\
\hline & \multirow{3}{*}{6} & Pelvis & I \\
\hline \multirow{2}{*}{ Visceral injuries } & & Kidney & 2 \\
\hline & & $\begin{array}{l}\text { Haemo/ } \\
\text { Pneumothorax }\end{array}$ & 4 \\
\hline
\end{tabular}


TABLE V

Survival

\begin{tabular}{ll}
\hline Less than 2 years & 2 \\
More than 3 years & 7 \\
More than 5 years & 2 \\
More than I0 years & 4 \\
\hline
\end{tabular}

TABLE VI

Operation at time of injury

\begin{tabular}{lr}
\hline No operation & I2 \\
Decompression laminectomy & 2 \\
Fusion & I \\
\hline
\end{tabular}

laminectomy (one with a fracture dislocation of $\mathrm{L}_{3}$ on 4 , and the other had a complete block at $T_{3}$ and avulsion of the $T_{3}$ nerve roots at myelography). In one case with fracture dislocation of TII on I2, spinal fusion was performed.

Hospitalisation. Four cases were admitted for more than I year (Table VII). The majority of patients stayed for 6 to 12 months. These periods included time spent in both an acute and a rehabilitation hospital.

Dressing ability. Thirteen children were totally independent in dressing activities. Of the two who were still dependent, one was aged 8 and had a neurological level at $\mathrm{T}_{4}$ and the other was aged II and had a level at $\mathrm{T}_{\mathrm{I}}$.

Transfers. Three patients aged 7, 8 and Io still required help with bed, toilet and bath transfers. Their injuries were at $\mathrm{C} 8, \mathrm{~T}_{4}$ and $\mathrm{T}_{4}$ respectively. Two children aged II and I5 with injuries at $T_{I}$ and $T_{3}$ needed help with toilet and bath transfers. Nine were totally independent (Table VIII). One patient aged 5,

\section{TABLE VII}

Length of time in all hospitals for first admission

\begin{tabular}{lr}
\hline Less than 6 months & I \\
Six to I2 months & IO \\
One year or more & 4 \\
\hline
\end{tabular}

\section{TABLE VIII}

Independence in transfers

\begin{tabular}{lrcc}
\hline & Bed & Toilet & Bathtub \\
\hline Dependent & 3 & 4 & 5 \\
Independent & 12 & II & 10 \\
\hline
\end{tabular}


injured at Tio, managed the bed and bath but, surprisingly, needed help on and off the toilet.

Ambulation. Only one patient was ambulatory, relying on one cane (Table IX); he had a cauda equina lesion. Eight patients with lesions from C8 to TI2 were exercise 'walkers', and all of these required above-knee braces and a walker or crutches. One additionally had a Harris type trunk support. The six cases totally confined to a wheelchair had neurological lesions from TI to TII and five of them were over 12 years of age.

Urinary tract status. Two patients with a TII and a cauda equina injury were continent of urine (Table X). One girl relied on a diaper and applied this herself. Seven males required a condom and collecting bag, and two of these, aged 5 and 7 , were dependent in managing the collecting apparatus. Two patients were on an intermittent catheterisation regime and managed this independently. Two had an indwelling catheter, which they changed themselves. One girl aged 22 had an ileal loop bladder. Despite her age, a visiting nurse applied the collecting apparatus for her alternate weeks.

Intravenous pyelograms had been carried out on 9 patients in the last 12 months (Table XI). The patient who had not had a pyelogram for over 5 years had a cauda equina lesion. He was continent and did not require any collecting apparatus. Of I4 patients with normal pyelograms, four had survived more than

TABLE IX

Ambulation

\begin{tabular}{ll}
\hline Ambulatory & I \\
Exercise standers or walkers & 8 \\
Wheelchair confined & 6 \\
\hline
\end{tabular}

TABLE X

Bladder status

\begin{tabular}{|c|c|c|c|}
\hline & & pendent & Independent \\
\hline Volitional continence & 2 & - & - \\
\hline Condom & 7 & 2 & 5 \\
\hline Diapers & I & - & I \\
\hline Indwelling catheter & 2 & - & 2 \\
\hline Intermittent catheter & 2 & - & 2 \\
\hline Ileal bladder & I & I & - \\
\hline
\end{tabular}

TABLE XI

Time elapsed since last IVP

\begin{tabular}{ll}
\hline Less than 6 months & 8 \\
Less than I year & I \\
Less than 2 years & 5 \\
Greater than 5 years & I \\
\hline
\end{tabular}


Io years. One patient, I I years, 7 months after injury had bilateral hydronephrosis and hydro-ureters. His urea nitrogen and serum creatinine were normal.

Bowel status. Ten patients had bowel continence. Seven of these used digital stimulation of the anus to initiate a motion and three additionally used a laxative or stool softener. Five were still having more than two accidents a month despite digital stimulation. Their ages ranged from 5 years, 3 months to II years, 6 months.

Schooling and employment. Seven of 12 patients receiving schooling were in the expected grade for their chronological age. Eight patients were attending a regular school (Table XII). Three had completed grade 9 and had left school.

Of four patients over the age of 16 , three were working, two of them part-time and one full-time. These three patients were also driving a car. One patient was still receiving full-time schooling.

Accommodation. Ten patients were still living with their parents and two with foster parents. Three over 20 years of age were living independently. No children were in an institution.

Spinal deformity. Eleven of 15 patients developed kyphoscoliosis. Two had flaccid, and nine had spastic lesions. The scoliosis was classified as mild or moderate in six patients and severe (a curvature of greater than $45^{\circ}$ ) in five. In eight of the scoliotic patients the lesion was at $\mathrm{T}_{4}$ or above. Three of the five patients with severe scoliosis had surgery at the time of injury. Two with a $\mathrm{T}_{3}$ and a cauda equina injury had decompression laminectomies, and in a TI2 patient spinal fusion had been carried out.

The subsequent surgery and the time this was performed following injury is shown in Table XIII. The interval was from 2 months to Io years. Cases with moderate scoliosis were treated conservatively with a fibre-glass moulded jacket or a trunk brace.

\section{TABLE XII}

\section{Schooling}

\begin{tabular}{ll}
\hline Regular class and school & 8 \\
Special school & 3 \\
Correspondence course & I \\
No schooling & 3 \\
\hline
\end{tabular}

TABLE XIII

Surgery in severe scoliosis (five patients curve $>45^{\circ}$ )

\begin{tabular}{|c|c|c|}
\hline Surgery at time of injury & Subsequent surgery & Time after injury \\
\hline I. Decompression laminectomy & Harrington and Dwyer & 5 years \\
\hline 2. Decompression laminectomy & Harrington & 2 months \\
\hline 3. No surgery & Harrington & 4 years \\
\hline 4. Spinal fusion & $\begin{array}{l}\text { Tibial band release } \\
\text { and psoas myotomy }\end{array}$ & Io years \\
\hline 5. No surgery & Harrington and Dwyer & 7 years \\
\hline
\end{tabular}




\section{Discussion}

The incidence of spinal cord injury in children has been reported as 3.3 per cent, 2.5 per cent and 5 per cent (Forni, 1947; Gelehrter, 1957; Gehrig \& Michaelis, I968) of all spinal cord injuries.

Melzak (1969) recorded 29 children with traumatic spinal cord lesions out of a total of 4470 patients with spinal cord lesions, but some of these were nontraumatic. Burke (1976) reported an incidence of 4 per cent and estimated 2.5 per cent to 5 per cent of spinal cord injuries in a Western community are children under the age of $\mathrm{I} 4$, or about 0.75 new patients per million population per annum. An average of 68 new traumatic spinal cord injuries per year occurred in B.C. from I97I to 1977. (Mowat, D. L., 1978.) This would indicate an incidence for children of at least $I \cdot 7$ per cent, taking into account a lesser overall incidence of traumatic spinal cord injuries prior to I97I, or 0.66 patients per million population per annum.

Of 29 patients that Melzak (1969) reported, no fracture of the vertebral column was detected in I6. Audic and Maury (I969) stated that in 2I children under the age of I6 with traumatic injury to the spine 'very often' no fracture was detected. Burke (I97I) reported normal X-rays in four of seven patients with spinal cord injury under age $\mathrm{I}_{3}$, and in a survey of a different group of patients in I974, I 2 of 24 had normal X-rays. Cheshire (1977) described three cases of traumatic myelopathy without demonstrable vertebral injury and assembled a total of I3 from the literature. He considered the injury to be due to either hyperflexion or hyperextension mechanisms. Seven of our 15 patients (47 per cent) had no radiological evidence of spinal fracture or fracture dislocation corresponding with these previous studies. Tomography at the time of injury might have shown more fractures. Injuries other than spinal were common and Io patients sustained is non-spinal fractures.

The neurological lesion was thoracic in 13 of 15 patients (87 per cent), and at $\mathrm{T}_{4}$ or above in nine. The predilection for the upper thoracic region may be due to tethering of the spinal cord by the cervical and lumbar plexuses, and infarction of long segments of the spinal cord may result from traction on the blood supply of the spinal artery (Burke, I976). Cheshire (I977) also hypothesised that longitudinal stretching is likely to be a major force in the pathogeneses of spinal cord injuries in children, which are not associated with evidence of skeletal injury. A high proportion of complete cord lesion (in our survey, I 3 out of I 5 cases, 87 per cent) compared with adults could possibly be explained on the greater elasticity of the young vertebral column, and thus a relatively greater force is required to injure the spinal cord, causing more severe damage (Burke, 1976).

As might be anticipated, motor vehicle accidents were a major cause of injury. It would appear that 'pedestrian' children are at greater risk ( 7 of I 5-47 per cent). No sporting injuries were noted in our series.

The time spent in hospitals for the first admission was greater than I year in four cases. The length of hospitalisation must have a serious impact on the child and his family. Many of these children require re-admission, especially for skin ulceration and spinal surgery.

Guttmann (I969) first drew attention to the risk of increasing spinal deformity by laminectomy, in which part of the important posterior supporting elements of the vertebrae were removed as well as further damage caused to the posterior ligamentous and muscular structures between the vertebrae. Morgan et al. (I97I) 
concurred that laminectomy was one factor leading to spinal deformity and contributing to its progression. All three of our patients who underwent early postinjury spinal surgery developed severe scoliosis and in two of these cases laminectomy had been carried out. Five of 15 ( 33 per cent) of our patients developed severe scoliosis. Four of these required Harrington instrumentation and two of these also had a simultaneous Dwyer procedure. All of our cases had early mobilisation. We feel getting the patient into the sitting or standing position too rapidly after initial injury may be another factor in the development of subsequent kyphoscoliosis.

In this series, most children ( 13 of 15 ) were independent in dressing and undressing. Nine of 15 (60 per cent) were totally independent in all transfers. One child dependent for toilet transfers was only aged 5. Surprisingly, he could manage a bed and bath transfer. The other five children who were dependent for transfers, all had lesions at $\mathrm{T}_{4}$ or above. Twelve of $\mathrm{I} 5$ patients ( 80 per cent) were continent of urine and able to manage their collecting apparatus, and Io of is (66 per cent) had bowel continence. The two males who could not manage their own condom and collecting bag were aged only 5 and 7 . One female, aged 22 , had to have a visiting nurse change her ileal bladder collecting bag alternate weeks.

Only one patient walked independently and he had a cauda equina lesion. Eight of I 5 patients enjoyed exercise 'walking', and bracing these children for this purpose alone was considered worth while, despite the fact that over the age of I 2 most children will be totally confined to a wheelchair.

Seven of 12 ( 58 per cent) children receiving schooling were at their expected grade level. Those below had fallen behind because of repeated hospitalisation for skin ulceration and surgery and/or because of psycho-social factors in their homes. Only three patients required special schooling and all of these patients had gross psycho-social problems which would have precluded attending any regular school setting. All children below age 20 at the time of this survey were living with their parents or in a foster home. None had ever been institutionalised. The employment prospect seemed very good with three of four of our children over the age of 16 in some type of remunerative employment and all three were driving their own cars.

The prognosis for these children is unknown. Burke (I974) reported that five of six patients who had survived Io to I8 years had pyelographic evidence of renal damage. Four of our cases had survived Io to I3 years. Only one of these had intravenous pyelographic evidence of hydronephrosis. All of our cases with less than Io years' survival had normal intravenous pyelograms. It seems likely that chronic pyelonephritis and hydronephrosis will limit the life span of at least some of these children (Burke, I976).

\section{Summary}

Fifteen patients with traumatic spinal cord injury below the age of 13 were studied to determine the aetiology, length of initial hospitalisation, incidence of spinal fracture and scoliosis, and subsequent spinal surgery. Their current status, including self-care, transfer and ambulatory abilities, bowel and bladder management, schooling, employment and place of abode was also reviewed.

The incidence was at least $\mathrm{I} \cdot 7$ per cent. In 87 per cent of patients the lesion was at $\mathrm{T}_{4}$ or above. Paralysis was complete in 87 per cent. No bony injury was recorded in 47 per cent. A great number of 'pedestrian' accidents occurred ( 7 of 15-47 per cent). Most children were independent in self-care and 66 per cent 
could transfer independently. Only one patient was a functional walker, although 8 of I 5 enjoyed exercise 'walking'.

Seventy-three per cent were continent of urine or independent in managing their collecting apparatus and 66 per cent had bowel continence. Fifty-eight per cent of children receiving schooling were in the correct grade for their chronological age and only three required a special school. No children had been institutionalised. Three of four over the age of 16 were in remunerative employment and driving their own cars.

Thirty-three per cent required surgery for severe spinal scoliosis. Two patients who had early post-injury laminectomies developed severe scoliosis and required subsequent surgical spinal stabilisation.

Four patients had survived more than Io years. Only one patient showed intravenous pyelographic evidence of hydronephrosis and hydro-ureters.

\section{RÉSUMÉ}

Nous avons étudié les dossiers de quinze patients qui ont subi une traumatisme de la moelle épinière, tous ces patients agés de moins de treize ans, afin de determiner, l'étiologie de la traumatisme, la durée d'hospitilisation, la frequence des fractures de la colonne vertebrale associés, et de la scoliose, ainsi que la frequence de la chirurgie vertebrale posttraumatique.

Aussi, nous avons determiné si ces patients étaient independent en faisant leurs soins personnels, leurs capacités ambulatoires, et leurs abilités de pouvoir transférer, et sils étaient independent en controllant leurs selles et leurs urines. Nous avons aussi étudié leur vie scolaire, leur capacité de travailler et leur habitation.

L'incidence était d'au moins $\mathrm{I} \cdot 7 \%$. $87 \%$ des patientt étaient blessés au niveau de la quatrième vertèbre dorsale ou à des niveaux plus haut. En $87 \%$ des cas la paralysie était complète, avec aucune lesion osseuse dans $47 \%$ des cas. Il y avait un grand nombre d'accidents comme pieton ( 7 patients, $47 \%$ ).

Le plupart de ces enfants se soignaient par eux-même, et en $66 \%$ des patients les transfères si faisaient de façon independent. Seulment un enfant pouvait marcher assez bien pour le permettre de fonctionner de la position debout, et 8 autres enfants employaient la marche comme une forme d'exercise.

$73 \%$ des patients pouvaient controller leurs urines, ou, sinon, pouvaient s'en occuper avec leurs appareils de collection urinaire sans aide. $66 \%$ des enfants se montraient capable de controller les selles. $58 \%$ des patients suivaient des études scolaires dans une classe approprié en niveau pour leur âge, et 3 suivaient des cours dans une école specialisée. Aucun des enfants sont dans un institution.

De quatre enfants maintenant agés de plus de 16 ans, trois travaillent et gagnent de l'argent, et conduisent leurs propres voitures.

$33 \%$ des patients avaient des lesions osseuses qui necessitaient des interventions chirurgicales pour correction de la scoliose sévere. Deux patients qui avaient des laminectomies post-traumatiques précoces, se montraient plus tard avec une scoliose sévère necessitant encore de le chirurgie pour le stabilization vertebrale.

Quatre patients ont survecu plus de ro ans depuis leur accident. Un seul de ces patients a demontré l'evidence d'hydronephrose et des hydro-uretères sur la pyelographie intraveineuse.

\section{ZUSAMMENFASSUNG:}

Fünfzehn Patienten unter I3 Jahre mit traumatischem Wirbelsäulenschaden wurden studiert, um die Vorgeschichte, Länge des einleitenden Krankenhausaufenthaltes, Vorkommen von Wirbelsäulenbruch und Skoliosis, sowie darausfolgende Wirbelsäulenoperationen festzustellen. Der derzeitige Zustand dieser Kinder, d.h. Fähigkeit selbständig zu essen, sich zu kleiden, Sitzgelegenheit zu wechseln, sich fortzubewegen, Blasen-und-Darmfunktion zu pflegen, wurde ebenfalls geprüft, sowie ihre Schulausbildung, Arbeitsplatz und Wohnsitz.

In mindestens $\mathrm{I} \cdot 7 \%$ wurde Rückenmarks Schaden festgestellt. In $87 \%$ der Patienten 
war die Verletzung in Höhe T-4 oder darüber. Totale Lähmung war in $87 \%$ zu verzeichnen, keine Knochenverletzung in $47 \%$. Verhältnismässig viele gewöhnliche Unfälle kamen vor (7 von 15 oder $47 \%$ ). Beinahe alle Kinder konnten selber essen, sich kleiden, und $66 \%$ konnten Sitz-oder Bettstatt ungehindert wechseln. Nur I Patient geht funktionnell, jedoch erfreuten sich 8 von 15 der Gehübungen.

Drei-und-siebzig Perzent zeigten Urinkontinenz oder waren imstande Urinsammelgeräte au pflegen, und $66 \%$ wiesen Stuhlkontinenz auf. Acht-und-fünfzig der Kinder, die zur Schule gingen, absolvierten die rechte Klasse für ihr Alter, und nur 3\% gingen in eine Sonderschule. Keines der Kinder lebte in einer Institution, 3 von 4 Kindern über I6 Jahre führten eine bezahlte Arbeit aus und fuhren ein eigenes Auto.

Drei und dreissig Perzent benötigten chirugische Eingriffe auf grund schwerer Spinaler

Skoliosis. Zwei Patienten, welche sofort nach dem Unfall einer Laminectomy unterzogen wurden, entwickelten schwere Skoliosen und benötigten chirurgische Rückgratsstabilisation.

Vier Patienten überlebten mehr als Io Jahre. Nur I Patient wies intravenöse pyelographische Anzeichen von Hydronephronis und Hyrdoureter auf.

\section{REFERENCES}

Audic, B. \& MAURY, M. (1969). Secondary vertebral deformities in childhood and adolescence. Paraplegia, 7, 10-16.

Burke, D. C. (I97I). Spinal cord trauma in children. Paraplegia, 9, I-I4.

Burke, D. C. (1974). Traumatic spinal paralysis in children. Paraplegia, II, 268-276.

BURKe, D. C. (1976). Injuries of the spinal cord in children. Handbook of Clinical Neurology, Vol. 25, 175-195. Edited by P. J. Vinken \& G. M. Bruyn, North Holland Publishing Company, Amsterdam.

Cheshire, D. J. E. (I977). The paediatric syndrome of traumatic myelopathy without demonstrable vertebral injury. Paraplegia, 15, 74-85.

ForNi, I. (1947). Le fratture del rachide nel bambino. Chirurgia, degli, Organi de morimento, 3I, 347-36I.

Gehrig, R. \& Michaelis, G. H. (1968). Statistics of acute paraplegia and tetraplegia on a national scale. Paraplegia, 6, 93-95.

Gelehrter, G. (1957). Die Wirbelkörbrüche in Kindes and Jugendalter. Archiv fur orthopädische und Onfall-Chirurgie, 49, 253-263.

Glasauer, F. E. \& CARES, H. L. (1972). Traumatic paraplegia in infancy. $\mathcal{F} A M A, \mathbf{2 1 9}$, 38-4I.

GutTMANN, Sir L. (1969). Spinal deformities in traumatic paraplegics and tetraplegics following surgical procedures. Paraplegia, 7, 38-49.

Melzak, J. (1969). Paraplegia among children. Lancet, 2, 45-48.

Morgan, T. N., Wharton, G. W. \& Austin, G. N. (I97I). The results of laminectomy in patients with spinal cord injuries. Paraplegia, 9, 14-23.

MowAT, D. L. (1978). Executive Director, Canadian Paraplegic Association, B.C. Division, personal communication. 